\title{
CMKLR1 wt Allele
}

National Cancer Institute

\section{Source}

National Cancer Institute. CMKLR1 wt Allele. NCI Thesaurus. Code C51438.

Human CMKLR1 wild-type allele is located in the vicinity of $12 \mathrm{q} 24.1$ and is approximately $48 \mathrm{~kb}$ in length. This allele, which encodes chemokine receptor-like 1 protein, may play a role in chemotaxis and bone metabolism; however, an exact function has yet to be elucidated. 